\title{
From the Germanic to the Soviet Accounting System (History of Czechoslovak Accounting after the World War Two)
}

\section{Vladimír ZELENKA* - Marie ZELENKOVÁ**}

This paper ${ }^{1}$ looks at the history of accounting in Czechoslovakia from the end of World War One to early 1960's. There are only some few works engaged in history of the Czechoslovak accounting of the second middle of the past century (Králiček, 1983; Klozar, 1994; Zelenka Zelenka, 1992; Zelenka - Zelenková, 2003). Although it is often difficult to establish clear demarcations, this paper attempts to break the time down into distinct periods and sub-periods in order to provide a description of the salient features of each:

- 1918 to 1945 , accounting during the First Republic and Protectorate;

- 1945 to 1946, post-World War Two accounting;

- 1946 to 1952, Singular System for Business Accounting;

- 1953 to 1965, National-Economic Evidence.

Although this paper is concerned primarily with the period following World War Two, it would also not be inappropriate, for the sake of historical context, to briefly describe earlier accounting. This paper thus starts with a brief summation of the accounting that existed in the pre1945 period.

\# The article is processed as an output of a research project of Faculty of Finance and Accounting, University of Economics, Prague, within a scope of institutional support VŠE IP 100040.

* Doc. Ing. Vladimír Zelenka, Ph.D. - associate professor; Department of Financial Accounting and Auditing, Faculty of Finance and Accounting, University of Economics, Prague, W. Churchill Sq. 4, 13067 Prague 3; <vzelenka@ vse.cz>.

** Ing. Marie Zelenková, Ph.D. - assistant professor; Department of Financial Accounting and Auditing, Faculty of Finance and Accounting, University of Economics, Prague, W. Churchill Sq. 4, 13067 Prague 3; <zelenm@ vse.cz>.

1 Many thanks to Mr. Robert Mládek for his help by translation of our paper Zelenka, Zelenková (2003), the main source for this article. 


\section{Accounting during the First Republic and Protectorate (1918 to 1945)}

Prior to the recreation of the independent Czechoslovak state (known as the First Republic), immediately following the First World War, the lands of the Czech Crown and Slovakia were part of the AustroHungarian Empire. It was thus natural, for the sake of continuity, First Republic accounting to be based on old Austro-Hungarian accounting. First Republic accounting was thus based on the Austrian commercial code $^{2}$ until World War Two.

While somewhat different from the Germanic accounting of this time, both of these norms were, as was the accounting of much of Continental Europe, heavily influenced by the Germanic model. In the Czech lands, most of these differences disappeared during the German occupation of World War Two. Thus, since the Germanic model of that period is comparable to the contemporary Germanic model, this paper does not provide a detailed description of its characteristics. Instead, it should suffice to mention the two most significant differences between this and the Anglo-Saxon ${ }^{3}$.

The first difference is that while the Anglos-Saxon model concerns itself with the end result (the financial report) and allows companies great leeway in respect to process, the Germanic model concerns itself with process and demands a strict adherence to this process ${ }^{4}$. In the second, while the Anglos-Saxon model concerns itself with financial reporting (leaving managerial and tax accounting separate and distinct from financial accounting), the Germanic model concerns itself with accounting as such, considering financial, managerial and tax accounting to be merely different aspects of a single system.

The implication of these differences is that while many of the features of the Soviet model of accounting (on which the Czechoslovak accounting since 1953 was based) will strike both Anglo-Saxons and

\footnotetext{
Österreichische Allgemeine Handelsgesetzbuch.

3 The term Germanic model denotes any accounting system that is statutory (such as contemporary German, French or Czech accounting). The term Anglo-Saxon model denotes any accounting that is conventional (such as IFRS, U.S. GAAP pr U.K. GAAP) and non-statutory, while the term Soviet model is used to denote the accounting systems used in the former Soviet Union and selected countries of the former Soviet-Block.

4 For example, require all companies to use a single, standard chart of accounts and to publish a set of standardized financial statements.
} 
Continental Europeans as odd, they will often strike them odd for different reasons. The other implication is that, if all three models were aligned and joined by a single straight line, the Germanic and AngloSaxon models would be at the two ends, while Soviet model would be somewhere in between.

\section{Post World War Two accounting (1945 to 1946)}

The period immediately following World War Two was a chaotic time throughout Europe. In the Czechoslovakia the most significant occurrence (from an accounting perspective) was the signing of Košice Political Program (Košický vládní program) in 1945. This program brought about the first wave of nationalizations officially sanctioned by the newly recreated Czechoslovak state (Lhota (1987)). The primary target of these nationalizations was, however, property in German and Hungarian hand and their aim was to place the property into Czech and Slovak hands. This period also saw the consolidation of Soviet power in Central Europe and the rise of Communism that accompanied it. Political historians have devoted much energy to the debate about whether Czechoslovakia had a choice, but the fact is that in 1948 the Communist party won what was generally considered a free and fair election.

At first these political changes had an effect on people and businesses, but not on accounting per se. Some minor changes in accounting were, however, necessary to reflect the new economic reality that that followed the nationalization of strategically important businesses (primarily mines, industrial companies, agricultural businesses, banks and insurance companies). These changes were, however, restricted to transferring the nationalized company's equity from its former owners to the state and replacing the title (and usually person) of owner with the title and person of 'people's administrator' (národní správce). Later the people's representatives (a.k.a. the state) created the institution of 'people's administration' (národní správa), which was charged with the task of administering the people's companies (národní podniky) (Lhota, 1987).

The management of the 'people's companies' themselves continued along Germanic lines with day to day operating authority in the hands of the management board (which comprised two-thirds state representatives and one-third union representatives). During the nationalization process, many managerial redundancies by first reducing individual nationalized companies to their component pieces (along industry lines) and then recombining the pieces into single companies. The business landscape 
was thus transformed from one of many small companies competing with one another in one or more industries into one of large companies each monopolizing its own industry. Although these companies all belonged to the people, from a legal perspective, they were still separate and distinct legal entities. During 1945 and 1946, 2,251 companies were nationalized with the result that, by 1946, approximately $60 \%$ of the Czechoslovak workforce was employed at the people's companies. The remaining $40 \%$ continued to be employed at private companies operating alongside of the new industrial giants (primarily in industries that were not considered strategically important to the people and agriculture, which was still dominated by small land-holders/farmers).

This new ownership structure first influenced the accounting system of people's companies (private companies continued to use the same accounting as before) by directive \#51/1948 Sb, was issued. This directive was accomplished by replacing the line items paid-in capital (because there was no more paid in capital) and accumulated profit and loss (because only private enterprise could generated a 'profit' that could be accumulated) with the single line item known as kmenové jmění. (This term does not have an exact English equivalent and so is not translated.)

In theory, kmenové jmění should have expressed the value of the people's assets entrusted by the state into the hands of the people's administrator. Kmenové jmění was, however, in practice defined as property, plant and equipment plus necessary inventory. Necessary inventory was defined as inventory necessary to the company's ongoing activity. People's companies remained the primary (and following 1952, with the exception of agricultural cooperatives or collectives, the only) business organization until the fall of communism.

\section{'The Singular System for Business Accounting' (Jednotná organizace podnikového početnictví) (1946 to 1952)}

From 1946 to 1952, Czechoslovakia enjoyed a mixed economy where approximately $1 / 2$ of the economy was under state control. The accounting system used during this period can be, in the whole, characterized as derivative form of the accounting that had existed since the days of the Austro-Hungarian Empire. Thus although a new law on accounting did come into force in 1946, the newly introduced Singular System for Business Accounting (Jednotná organizace podnikového početnictví5),

\footnotetext{
${ }^{5}$ The term početnictví is not the same as the term účetnictví, the traditional Czech term for accounting. The different terminology was intended to draw attention to the fact
} 
was not, aside from its new name, a major departure from previous accounting norms (Fiala (1947), Fiala - Partyk (1948), .

Aside from the fact that it instituted a new term for accounting, it refined the older system by further integrating financial and managerial accounting by, among other things, applying certain managerial accounting concepts such as forecasting and budgeting to the task of calculating financial income. This is not to say that no major accounting changes occurred during this period. Many did. But, most of these changes were a result of a shift in society itself, and the reaction of accounting policymakers to this shift, rather than a shift in accounting theory itself. To summarize:

- In 1946, communist party wins a plurality in the general election.

- In 1947, the first two-year plan introduced by the transitional government. This plan was drafted with the intent of repairing the damage caused by World War Two.

- In 1948, communist party consolidates power and supplants the remaining political parties. Soon thereafter, the second wave of nationalization begins. Unlike the first wave, this wave is aimed not just at formerly German and Hungarian owned businesses and strategic industries, but at most private enterprise. In the same year the state also introduces price controls for most products and services.

- In 1949, communist party sets regulated prices for all remaining goods and services and nationalizes any remaining enterprises.

State ownership (term people's ownership was replaced) of all productive assets did not, at first, have a dramatic impact on accounting practice. The reason is that state ownership did not eliminate the need for productive enterprises to interact with consumers and among themselves. It did, however, significantly streamline accounting thought because it was no longer necessary to devise all manner of complex accounting procedures needed by an economy where consumers, business owners, managers, creditors and investors all act and interact more or less independently and of their own free will.

that the new system was not in fact a 'financial accounting system'. Instead, the new system was intended to be a 'managerial information system'. However, given the fact that this new system did not, in any practical way, differ significantly from the old and the term 'management information system' has a different contemporary meaning, the term početnictví is also translated as accounting. 
Thus, in these heady times, accounting theorists saw no logical reason to divide the credit side of the balance sheet into liabilities and equity. Since the state owned everything, it was the only possible as well as creditor, keeping track of who owed whom and so who owned what was comparable to keeping track of left pocket's debt to the right. Likewise, since all the value produced by everyone belonged to the state, there was no logical need to calculate something like taxable income, since this would be comparable to the state's taxing itself.

Unfortunate, state control of prices and business decisions brought other complications. Since the market could no longer serve as the arbitrator of value, then role fell to state planners who, unfortunately, were often far removed from individual economic decisions. Thus, an accounting system had to be designed to keep this decision making power in the hands of the people closest to these decision (company managers) but at the same time to make sure that they made decisions that benefited the state rather than just decisions that benefited individual state enterprises.

To cope with this dilemma, the new system of accounting did not fully incorporate all the potential time saving features conceptually allowed by the new economic system, and remained company centric. On the other hand, it implemented specific guidance as to planning and budgeting coupled with specific reporting guidance that would provide individual administrators with a consistent framework and the incentive to act in the interest of their company. The major features of this accounting system can be summarized as follows:

- The system was, theoretically, two separate and distinct systems: one designed for reporting and the other for costing. These two systems were, however, connected and fused into a single whole by formal procedures.

- For reporting purposes, a single general chart of accounts was made mandatory for all companies. Very little (and then strictly industry specific) variance from the standard was permitted. In summary it contained the following major classes:

$0 \quad$ Tangible and intangible assets

1 Inventory

$2 \quad$ Financial assets and liabilities

3 Expenses

4-7 Costing (internal managerial) accounts

8 Revenue 
$9 \quad$ Equity and closing accounts

In contrast to the strictness and uniformity of the reporting half of the system, the costing half (as will be seen later) enjoyed significant flexibility.

- Reported income was technically the difference between total revenues and total expenses. However, since both purchaser and sales prices were regulated, the value of reported income was, more or less, arbitrary. Also, since the nature of expenses method was used, changes in inventory and self-manufactured assets were included in revenue and expenses.

Since the blending of financial and costing procedures was the most distinctive feature of this system, it would be appropriate to discuss this aspect in more detail. Although numerous variations existed in practice, the following three general methods (presented here in order of incidence of application) were employed:

\section{Socialist Business Economics (SBE) \\ (Socialistické podnikové hospodářství-SPH)}

This system was a derivative of a system originally implemented by Tomáš Bat'a (the successful Czech shoemaker who eventually emigrated to Canada) at Bata Zlín. This system was based on the concept of autonomous business units that were judged on the basis of cost of production. More specifically, this system compared actual and budgeted costs and actively tried to minimize variances. Input for this system came from financial accounting and thus actual cost was equal to historical cost (which, with state regulated prices, was not, however, equal to fair value).

\section{Aggregate Business-Unit Accounting (ABA) (Úplné střediskové účetnictví)}

This method, originally introduced by author L. Lazar, was similar in concept to SBE, but viewed business from the opposite perspective. Similarly to SBE, ABA also broke the enterprise down into autonomous business units. But, unlike SBE, it did not merely track cost by business unit. Instead, it treated each unit as a separate business (tracking revenue and expenses, and most assets and liabilities at this level). To generate financial reports for the whole entity's, ABA merely aggregated the components. 


\section{Company Self-management (CSM) (Podniková samospráva)}

This method could be viewed as an opposite to ABA in that it was similar to SBE in perspective but took the opposite conceptual view. CSM thus focused on cost, but rather than attempting to evaluate cost at the business unit level, looked at cost at the company wide level. Of the three, it was the least often used.

Also important to note, while the 1946 to 1952 period can be viewed, from the accounting methodology perspective, as a single, unified period (since no significant changes to the accounting system, as such, were implemented), from the social/political vantage point it should be broken down into two distinct and separate sub-periods: the pre-1948 mixed economy period and the post 1948 period of collectivism.

During the pre-1948 period, both national and private companies coexisted side by side. The primary difference between the two was not that one strived to generate a profit and the other did not, but rather that the national companies turned over what profit they did generate (less $20 \%$ set aside as a reserve and $10 \%$ transferred to unions) to the state. The state also strived to support strategically important state companies even when these were not profitable. Thus, even though the state did occasionally transfer some of the profits generated by the profitable nationalized companies to their former owners this occurred rarely as most profits were consumed by the unprofitable state companies. The mechanism for the receipt and distribution of these funds was a so-called adjustment account at the Ministry of Finance.

Between 1949 and 1953 the pace of nationalization (with some 4,895 additional companies being nationalized) picked up. The distinctions between national and nominally private companies began to fade and by the end of this period (with the exception of agriculture, which resisted nationalization throughout the whole period of communist rule), private enterprise ceased to exist (even in name) (Lhota (1987), Ullmann (1994)).

To reflect this new reality, the adjustment account was transformed into the Nationalized Property Fund ${ }^{6}$ to which all commercial enterprises were now obligated to turn over all profits. For a time following 1948,

6 An interesting side note is what a difference a few letters can make. The Nationalized Property Fund was an institution devoted to seizing people's property for the benefit of the people. The National Property Fund, created following the fall of communism, is an institution devoted to giving the people's property back to people. 
both national $^{7}$ and nationalized ${ }^{8}$ continued to exist along side one another. The latter were, however, obligated to turn over all their income (less a $10 \%$ charge paid to unions and a $60 \%$ income tax) to the state.

The economic result of this system was that the management of neither national nor newly nationalized companies was particularly motivated to generate a profit, since what profit they did generate was turned over to the state. Absent a profit motive, it was thus up to the state to determine where companies would invest. The mechanism for this investment was relatively simple in concept. State planner drew up a plan of goods and services required by the state and then provided companies the fixed assets (or the funds necessary to acquire these assets) deemed to necessary to meet the plan. Since companies still had to interact with one another, the state also created a commercial bank were companies kept working funds. Since companies still had to interact with one another, the state also created a bank were companies kept working funds. Companies were thus obligated to segregate money's received for capital acquisitions and money's received for day-to-day operations. The former was kept on account at the Investment Bank, while the latter was kept on account at the Czechoslovak National Bank. At one point in time, two physically and administratively distinct banks did exists. Within a few years, this system was adjusted and the Czechoslovak National Bank kept all accounts for all companies for this purpose. Companies were, however, obligated to maintain two separate accounts for these purposes.

The implications, from an accounting methodology perspective, was that companies were, for the first time in Czechoslovak history, required to differentiate and keep separate funds needed for general operations and funds earmarked for capital acquisitions. The commingling these two fund pools was prohibited. Also, since companies could not lend to on another, and since their working funds were provided by operations, lossmaking companies were required to file a loss report with the Ministry of Finance, and the state compensated them for these losses (by transferring fresh working funds).

Since the new economic system was considerably different from the one it replaced, not only company managers but the state was faced with numerous challenges as it attempted to draft new accounting and

7 Companies had been nationalized in the prior period and whose component pieces were reorganized and rearranged into new entities.

8 Companies that now belonged to the state but that the state had not yet had the opportunity, in these frenetic times, to assimilate. 
procedural rules to reflect the new reality. The following is a summary of the more interesting of these.

Under the new system, companies were not required to buy their fixed assets; the state provided them (or the funds to buy them). Companies were, however, required to compensate the state for the use of the state's assets. Thus, under this accounting system, depreciation ceased to be a non-cash charge. Companies turned over an amount, equal to the depreciation of assets, to the state. Also, since the assets provided by the state were not, technically, grants, the state charged companies interest (equal to 3.5\% of the acquisition price of the asset) (Pásek (1948)).

By 1953, the state also completed the unified pricing system. This system established fixed prices for all goods and services (consumer and producer). Unfortunately, producer goods prices and consumer goods prices were set independently of one another. This mismatch often lead to the situation where a company was obligated to pay a higher price for its inputs than it was allowed to sell to consumers and where it could sell to other companies for considerably higher prices than it could sell to consumers. During this time, management authority at individual companies was severely constrained and so loss compensation filings with the Ministry of Finance became common. This in turn led to some interesting reactions, in an attempt to minimize these reimbursements, from the state. For example, instead of taking the unpopular step of trying to coordinate consumer and producer prices, the state established a system of special charges that were levied against companies incurring excessive costs. Companies meeting their cost targets earned reductions in these charges.

\section{'National-Economic Evidence' (Národohospodářské evidence) (1953 to 1965)}

In the early $50 \mathrm{~s}$, the communist party realized, with considerable consternation, that the accounting system currently in use was, in fact, a capitalist accounting system. The party's members thus told themselves that it was natural that the newly installed people's economy had gotten off to a rocky start. It had, after all, inherited an accounting system that had, from the foundation up, been designed to serve the capitalist exploiters. Further, they concluded that this system was not merely misdirected, but that is was part of the world-wide capitalist conspiracy to undermine, belittle and subvert the new communal order and thus prevent it from becoming the productive and egalitarian envy of the world that it 
was destined (as Marx said) to be. Since no manner of remodeling could save this old house, it was torn down, razed, foundations riven and a new house, built by and for the people, was put in its place.

Since the Soviet Union had already, many years before, shed the yoke of capitalist oppression, it was natural for its accounting system to serve as the paradigm after which the new Czechoslovak system was modeled. So, on January 1, 1953, The Singular System for Business Accounting was unceremoniously taken out to the trash heap of history and Book-Keeping Evidence (Účetní evidence) incorporated in National-Economic Evidence system was put in its place 9 (Blecha (1960), Fiala (1954), Fireš - Vihan (1963), Peroutka - Zavadil (1954).

As all things in the communal state, so was this accounting system ${ }^{10}$ subordinated to the central plan. In general, the system required evidentiary entities ${ }^{11}$ to keep financial records, make individual accounting entries and archive accounting documents according to detailed procedural rules primarily for the purpose of being able to produce detailed financial reports on which the state's planners could base their plans.

Thus, since this system was a reporting rather than management information system, it did not address any of the managerial accounting issues addressed by the former system, which were moved 'off the books,' but focused on the financial report. Since the new system did not formally address most ${ }^{12}$ managerial issues, managers were, for the first time in Czech history free use their own judgment and construct internal procedures according to their particular needs of their particular evidentiary entities.

9 For those who had been raised in the belief that the purpose of accounting was to facilitate the rational and effective allocation of capital, January 1, 1953 was a dark day indeed. This was the day that accounting definitively ceased to serve the needs of the individual (person and enterprise) began to serve the needs of the collective.

10 The system was formalized in the Law of Organizational National-Economic Evidence (Zákon o organizaci národohospodářské evidence), administrative directive \# 41/1952 and various implementation guides issued by the Ministry of Finance.

11 The system did not refer to companies as companies (as this implies a separate existence apart from the collective whole), but, since they were in fact distinct from one another, it refers to entities engaged in a particular activity about which they provided financial reports as evidentiary entities. This paper also uses this term to refer to what could also be referred, under a different system of accounting, as an enterprise of business.

12 The only managerial aspect formally addressed by the new system was cost-variance analysis. 
The system, because it was based on a different view of the role of enterprise, represented a true, theoretical break with the accounting of the past and introduced many new procedures and concepts. Among these was the discontinuation of the profit and loss statement (since communal evidentiary entities could not, from a philosophical perspective, strive to earn a profit). Instead, revenues and expenses were charged a realization account, which was then closed to a result of operations (vysledek hospodarení) account from which state charges were deducted. The remainder was then transferred to the capital account where it was accumulated and divided up into a variety of reserve accounts. The result of operations also became the primary indicator of an evidentiary entity's economic performance. Thus, while difference between revenues and expenses could no longer, legally, be referred to as a profit or loss, even the communal ideology, even a system based on communal ideology could not escape the necessity of gauging economic performance without it. To get a better picture of economic performance, the new system also did away with the old nature of expense classification scheme and installed a new function of expense approach. Expenses were thus divided into production and non-production (a classification for selling, since companies had no official need to expend resources in securing a market for their produce, was not, however, considered necessary). Finally, to get a better picture of the objective value of an evidentiary entity's resources, all assets were measured at historical cost and the asset side of the balance sheet itself remained divided into two sections: operations and investments.

The operations section kept track of money's received and paid during day-to-day operations (amounts received from the sale of goods and paid for such expenses as material and wages). The investments area kept track money's received for the acquisition of long-lived assets. In this respect Book-Keeping Evidence took the same approach as the Singular System for Business Accounting had before it in that evidentiary entities received their long-lived assets by grant from the state and then repaid the state funds equal to the depreciation of these assets ${ }^{13}$.

In keeping with the communal sprit of the times, the balance sheet did not contain a classification for intangible assets because, since there was

${ }^{13}$ In practice, this was generally a nominally cash charge, since it mostly involved the entity's transferring funds from its operating account to its investment account. This system was used (with the occasional minor adjustment) throughout the communist period and into the early 90s. 
no intellectual property, such a class was superfluous (what intangible asset transactions did arise, for example licensing fees or permits, were treated as long-term prepaid expenses).

Another feature that significantly distinguished the old system and the new was that the latter eschewed for strict standardization favored by the former. Thus, instead of all evidentiary entities being required to use a single standardized chart of accounts and issue a single set of standardized financial statements, each industry got its own, custom designed, chart of accounts and financial statements. By 1954, 31 such charts of accounts existed.

The following is an example of the basic classes of such a chart for an industrial evidentiary entity:

1 Property, plant and equipment

2 PPE in progress and major repairs

3 Material

4 Wages

5 Production

6 Finished products and merchandise

7 Shipped goods and work performed

8 Cash

9 Receivables and payables

10 Pre-paid expenses

11 Separated resources

12 Relationship between entity and superior organs

13 Reserves

14 Provisions and an accumulated depreciation

15 Revalued inventory

16 State financing

17 Project financing and income

18 Financing of PPE and general repairs

19 Short term loans from State bank

20 Unearned income

21 Internal receivables and debts payable

22 Variance from planed and actual costs

23 Non-production expenses

24 Realization

25 Result of operations

26 Off balance-sheet accounts 
The final major difference between the old system and the new was that the new required timely reporting. Companies could thus no longer prepare merely annual (or semi-annual reports), but had to prepare them monthly. Taken together, these changes made the new system a radical departure from the old.

At this point, it is also necessary to note that many readers of this paper may not find many of the changes to be that unusual. For example, some of the most radical aspects of Book-Keeping Evidence, the classification of expenses by function, the absence of a single standardized chart of accounts (and general ledger), the strict adherence to historical cost, the focus on more frequent reporting will seem perfectly normal to an accountant versed in 'Anglo-Saxon' systems of accounting. Readers from continental Europe, accustomed accounting systems such as those used in France or Germany, will, however, agree, that these accounting principles do represent a radical departure from principles on which their own system of accounting are based.

The precedent Singular System for Business Accounting was designed primarily for the purpose of providing information to the state, which used this information in levying income taxes. From this perspective it is logical that the accounting system was standardized with each entity using one single chart of accounts and publishing one single set of financial statement. Likewise it is logical that it used nature of expense income statement classification (since this makes comparisons of enterprises). However, such a system is logical if, and only if the state and the individual enterprise remain two separate and distinct entities. Under the 'communal philosophy' on which Soviet accounting was based, no such distinction is made. The reason is that since everything belongs to everyone, the state and the commercial enterprise are in fact merely organs in the collective body.

The communist state had an entirely different goal: to make the pie, which belongs equally to everyone, bigger by managing production in the most effective manner possible. Look at critically, the Soviet system of accounting thus bears striking similarities to the Anglo-Saxon model. Like the Soviet model, it too is designed to help the pie grow. There is, however, one difference between the two models. Anglo-Saxon works while the Soviet model failed to work.

The Soviet model, like the Anglo-Saxon, may have been designed to provide true and fair information about economic activity. While the Anglo-Saxon model puts economic information into the hands of 
individual investors and relies on their own selfish interest to guide them to use this information to make investments that benefit society (as well as themselves), the Soviet model put this information into the hands of state planners who did not base their decisions on what people actually wanted (which, with fixed prices, they could not have determined in any case), but what the planners decided that people should want. The result was that the Soviet system did produce a growing economic pie. Instead it led to a squandering of resources so vast that no historical precedent exists.

The Czechoslovak system derived from Soviet accounting model called the National-Economic Evidence, while it contained many reasonable and logical elements, seemed to lack a rational, unifying theme, at least to the Czech accounting professionals asked to apply it in practice. The reason was that the rapidity of its introduction did not allow for the requisite reeducation of accounting professionals in the logic of the new system. In consequence, its application in practice was spotty and inconsistent with many practitioners adjusting to the new performance based reporting regime by trying to 'game the system' for their own personal benefit ${ }^{14}$.

For the state, the result was that the state was beginning to have problems living up to its own economic expectations. This became especially evident after 1958 when almost immediately after it was passed, it became clear that the current five-year plan could and would not be met. In an attempt to rectify this situation, several changes were made to the central planning system. The gist of these changes was to delegate more operational authority to company managers but, since the system of ridged price controls was left in place, individual managers, trying to maximize reported performance in as reported by the new accounting system, quite rationally shifted production from consumer to producer products. The resulting masses shortages of even the most basic consumer necessities and vast surpluses of items that no one wanted to buy. In 1961, strict central planning was reintroduced. These economic problems influenced huge changes in Czechoslovak Accounting in the middle of 1960's.

${ }^{14}$ An interesting footnote to this accounting period was law \# 54/1952 Sb. This law stated that a company's chief accountant was to be the state's independent representative and his or her primary duty was to act as the state's agent in guaranteeing that the company's book-keeping evidentiary system as in keeping with all norms and requirements. 


\section{Conclusion}

Political and economic changes in Czechoslovakia after the World War II also had a major impact on accounting. The accounting system applied immediately after the World War II follows up the accounting system of the First Republic and the Protectorate. In 1946, the Singular System of Business Accounting was adopted. It also came from Germanic accounting system based primarily on information required by the state for tax purposes. Singular System of Business Accounting consisted of a part dealing with financial reporting, and also a part focusing on costing. During the period of Singular System of Business Accounting the major political and economic changes occurred in 1948, Czechoslovakia finally moved from mixed to collectivist centrally controlled economy under the rule of the Communist Party of Czechoslovakia.

These changes did not have major impact on the accounting system applied in Czechoslovakia immediately, there were only partial revisions. The adoption of National-Economic Evidence System, including a BookKeeping Evidence, meant a fundamental change in accounting for Czechoslovakia. This change was mainly caused by the fact that the communist regimen considered the current accounting system to be primarily a capitalist system. The new accounting system was strictly based on the Soviet accounting model, and lasted until 1965. It is interesting to note that, formally, the Soviet model has some features similar to Anglo-Saxon model of accounting. Regarding its application in the conditions of collectivist Soviet regimen, however, it couldn't work effectively.

\section{References:}

[1] Blecha, J. (1960): Základy účetní evidence (účetnictví). Praha, Karlova universita, 1960.

[2] Fiala, J. (1947): Podnikové účetnictví (v jednotné organisaci podnikového početnictví). Praha, Orbis, 1947.

[3] Fiala, J. (1954): Základy účetní evidence. Praha, Orbis, 1954.

[4] Fiala, J. - Partyk, B. (1948): Podnikové početnictví I a II. Praha. Státní nakladatelství. 1948.

[5] Fireš, B. - Vihan, S. et al (1963): Základy teorie účetní evidence. Praha, SNTL, 1963.

[6] Klozar, J. (1994): Československé účetnictví ve druhé polovině 20. století. Manuscript. 1994. 
[7] Králiček, V. (1983): Vývoj československého účtovníctva v rokoch 1946-1976. Účetnictví-Účtovníctvo, 1983, no. 1, pp. 33-37, no. 2, pp. 75-80.

[8] Lhota, V. (1987): Znárodnění v Československu. Praha. Svoboda. 1987.

[9] Pásek, T. (1948): Financování národních podniků. Praha. Tiskové podniky Ústředního svazu čs. průmyslu. 1948.

[10] Peroutka, M. - Zavadil, V. (1954): Rozvaha průmyslového podniku a její rozbor. Praha. Orbis. 1954.

[11] Procházka, V. (1947): Finanční účetnictví průmyslových podniků. Praha. Tiskové podniky Ústředního svazu čs. průmyslu. 1947.

[12] Ullmann, B. (1994): Zahajovací rozvahy, jejich metodika, konstrukce a využití prí likvidaci liberální obchodní činnosti v bývalé ČSR. Praha, VŠE v Praze. 1994. Doctoral thesis.

[13] Zelenka, I. - Zelenka, V. (1992): Rechnungswesen in der ČSFR. Zeitschrift für Rechnungswesen. 1992, no. 8, pp. 22-23.

[14] Zelenka, V. - Zelenková, M. (2003): Looking for Rationality in the Unlikeliest of Places. A Historical Look at Accounting Practices in Communist Czechoslovakia. In: 26th Annual EAA Congress. Sevilla, European Accounting Association, 2003. 


\title{
From the Germanic to the Soviet Accounting System (History of Czechoslovak Accounting after the World War Two)
}

\author{
Vladimír ZELENKA - Marie ZELENKOVÁ
}

\begin{abstract}
The development of accounting in Czechoslovakia after the World War II was influenced by political and economic changes of that time. Firstly, it is a subject to tradition, and then also the political order. It results in the transition from the Germanic type of accounting to the Soviet model of accounting, i.e. from the Singular System of Business Accounting to Book-Keeping Evidence under the National-Economic Evidence. Although the Soviet accounting system is by some formal characteristics based on the Anglo-Saxon model of accounting, it was unable to operate efficiently in terms of collectivist economies of the communist regime, i.e. neither in Czechoslovakia.
\end{abstract}

Key words: Accounting History; Czechoslovak Accounting; Socialist Accounting.

JEL classification: M41. 